
\title{
25 Research Square \\ Effects of Kefir on Behavior, Immunity, and the Gut Microbiome in Mice
}

Marcel van de Wouw

Aaron M. Walsh

Fiona Crispie

Lucas van Leuven

Joshua M. Lyte

Marcus Boehme

Gerard Clarke

Timothy G. Dinan

Paul D. Cotter

John Cryan

\section{Video Byte}

Keywords: Microbiota, Kefir, Mouse, Brain, Behaviour, GABA, Immunity, serotonin, Reward, Lactobacillus, Microbiome, yogurt, probiotic

Posted Date: October 29th, 2020

DOl: https://doi.org/10.21203/rs.3.rs-100319/v1

License: (9) (i) This work is licensed under a Creative Commons Attribution 4.0 International License. Read Full License 


\section{Abstract}

We already know that eating good food makes our bodies feel good, but what we eat can also affect our brains. Microbiota that reside in our guts influence behavior through a mechanism called the microbiotagut-brain axis. Certain foods - including prebiotic, probiotic, and fermented foods - have received attention for their mood-boosting benefits. Now, a new study adds another food to that list. Kefir, a fermented food produced from a combination of live bacteria and yeasts, is known to affect the gut microbiota, but whether it affects the microbiota-brain axis and behavior is unclear. Researchers fed mice two different types of kefir and examined their behavior and their gut microbes. They found that feeding kefir reduced stress-induced hormone signaling and reward-seeking and repetitive behaviors in the mice. Different kefirs affected different types of behaviors and changed the abundance of specific bacterial species in the gut. While further study is needed to connect the microbial changes and behavioral effects, the results show that kefir can affect the microbiota-gut-brain axis in mice, suggesting that kefir should be studied as a potential dietary intervention to improve mood and behavior in humans. 